OPEN ACCESS

Edited by:

Simone Baldanzi,

Universidad de Valparaiso, Chile

Reviewed by:

Mauricio F. Landaeta, Universidad de Valparaiso, Chile

Maik Tiedemann,

Norwegian Institute of Marine

Research (IMR), Norway

${ }^{*}$ Correspondence: Paula Pattrick

paula.pattrick@gmail.com

Specialty section:

This article was submitted to Population, Community,

and Ecosystem Dynamics,

a section of the journal

Frontiers in Ecology and Evolution

Received: 23 March 2021

Accepted: 10 May 2021

Published: 31 May 2021

Citation:

Pattrick P, Weidberg N,

Goschen WS, Jackson JM,

McQuaid CD and Porri F (2021)

Larval Fish Assemblage Structure at Coastal Fronts and the Influence

of Environmental Variability.

Front. Ecol. Evol. 9:684502.

doi: $10.3389 /$ fevo.2021.684502

\section{Larval Fish Assemblage Structure at Coastal Fronts and the Influence of Environmental Variability}

\author{
Paula Pattrick 1,2,3*, Nicolas Weidberg ${ }^{3,4,5,6}$, Wayne S. Goschen ${ }^{1}$, Jennifer M. Jackson²,7, \\ Christopher D. McQuaid ${ }^{3}$ and Francesca Porri2,3
}

\begin{abstract}
${ }^{1}$ South African Environmental Observation Network, Elwandle Node, Nelson Mandela University, Ocean Sciences Campus, Gqeberha, South Africa, ${ }^{2}$ South African Institute for Aquatic Biodiversity, Makhanda, South Africa, ${ }^{3}$ Coastal Research Group, Department of Zoology and Entomology, Rhodes University, Grahamstown, South Africa, ${ }^{4}$ Norges Fiskerihogskole, Arctic University of Norway, Tromsø, Norway, ${ }^{5}$ Department of Biological Sciences, University of South Carolina, Columbia, SC, United States, ${ }^{6}$ Coastal Ecology Group, University of Vigo, Vigo, Spain, ${ }^{7}$ Hakai Institute, Victoria, BC, Canada
\end{abstract}

Within the coastal zone, oceanographic features, such as fronts, can have major effects on the abundance and distribution of larval fish. We investigated the effects of fronts on larval fish assemblages by jointly collecting physical (ADCP and CTD) and biological (larvae) data in the nearshore waters of the south coast of South Africa, on four separate neap-tide occasions. Accumulation of fish larvae at predominantly internal wave-associated fronts was observed, with higher larval densities inshore of and within the front than farther offshore. On each occasion, larvae of coastal species with pelagic eggs (Mugillidae and Sparidae) were numerically dominant at the front itself, while inshore of the front, larvae of coastal species with benthic eggs (Gobiesocidae and Gobiidae) were more abundant. Offshore catches mainly comprised Engraulidae (pelagic species with pelagic eggs) larvae, which were generally restricted to the bottom, where current velocities were onshore on each occasion. On the occasion when fast (>100 cm/s) currents prevailed, however, accumulation of the larvae of coastal species occurred offshore of the front, and larvae were mixed throughout the water column. Thus, larval occurrence at these coastal frontal systems was strongly affected by the degree of mixing by currents, which on most occasions resulted in onshore retention. The results underline the importance of frontal systems in determining the nearshore distributions of fish larvae, particularly by retaining coastal fish species in the inshore region. The environmental variability observed at these frontal systems has potential implications for larval connectivity of fish populations.

Keywords: ichthyoplankton, transport, retention, accumulation, larval behaviour, coastal fronts, internal wave

\section{INTRODUCTION}

The early life history of coastal marine fishes is complex, and most species have a dispersive pelagic larval stage that is followed by a settlement phase when juveniles seek suitable habitats (Moser et al., 1984; Leis, 1991a; Lecchini et al., 2005). A dispersal phase has major implications for population dynamics as it is during the pelagic larval stage that the spatial scales for adult connectivity and the 
geographic sizes of populations are set (Cowen, 2002; Sale, 2004). Understanding the mechanisms that influence the distribution and transport of pre-settlement larvae remains, however, a major challenge given the dynamic coastal environment in which dispersal takes place.

It has long been believed that ocean currents can transport propagules over extensive distances, and indeed large-scale circulation can extensively disperse fish larvae $(>100 \mathrm{~km})$ (Leis, 1984), though small-scale processes have been found to play an important role in local larval advection, retention and concentration (Black et al., 1990; Limouzy-Paris et al., 1997; Reiss et al., 2000). Recent studies have indicated that dispersal among marine populations frequently occurs at much smaller geographic scales than previously perceived (Sponaugle et al., 2012; Hameed et al., 2016), and a high degree of selfrecruitment sustains some fish populations (Swearer et al., 1999; Almany et al., 2007). In fact, a very reduced exchange of individuals between subpopulations is thought to be enough to keep a minimum genetic structure at the level of the metapopulation (Slatkin, 1993). Limited dispersal may be driven by oceanographic circulation and/or active larval behaviour, which can potentially serve to reduce spatial displacement (Kingsford, 1990; Cowen and Castro, 1994).

In the ocean, frontal regions are vertical boundaries between water masses of different physical, chemical and hydrodynamic properties (Wolanski and Hamner, 1988). Such hydrographical features, which can be up to hundreds of kilometres long, can have a positive or negative impact on larval fish survival and dispersal (Parrish et al., 1981; Norcross and Shaw, 1984; Bakun, 2006; Pineda et al., 2007). Fronts often visually manifest at the surface as lines or slicks (Moser and Smith, 1993). In essence, fronts are regions where horizontal currents converge separating different water types. The convergence of water leads to the accumulation of material and organisms with positive buoyancy and/or active vertical swimming capability (Franks, 1992b; Genin et al., 2005). Fronts can act as barriers for currents resulting in transport to potential coastal nurseries, increase in connectivity via wider dispersal, or advect aberrant larvae to unsuitable offshore regions where mortality can be high (Rodríguez et al., 2004; Pineda et al., 2007; Bolle et al., 2009; Mullaney and Suthers, 2013). In the same geographic region as the present study, the larvae of invertebrates caught up in offshore meanderings are mostly lost (Jackson et al., 2012; Porri et al., 2014; Weidberg et al., 2015).

The inshore region ( $<30 \mathrm{~m}$ deep) serves as an important habitat for the early developmental stages of many coastal as well as some pelagic fish species (Lasker, 1978, 1975; Myers and Pepin, 1994; Laprise and Pepin, 1995), providing ample food availability, refuge from large pelagic predators and suitable physicochemical conditions for optimal growth and development (Brewer and Kleppel, 1986; Laprise and Dodson, 1993).Within the coastal zone, fronts that occur at scales of less than several kilometres, scales that are relevant for fish larvae, are not well studied even though they are believed to act as mechanisms of aggregation, onshore transport, and retention for fish larvae (Shanks, 1983; Kingsford and Choat, 1986; Bakun, 1997;
Pineda, 1999, 1994; Woodson et al., 2012; Greer et al., 2014; Liévana MacTavish et al., 2016). The accumulation of larvae at fronts suggests that pre-settlement larval fishes may aggregate at these convergent oceanographic features during their pelagic phase (Shanks, 1983; Kingsford and Choat, 1986; Kingsford et al., 1991) or respond to fronts by seeking out high food abundance there due to particle aggregation (Kingsford, 1990).

We investigated the role of coastal fronts as potential transport and accumulation mechanisms for fish larvae in nearshore habitats of the eastern Agulhas Bank along the temperate south coast of South Africa, a region that is influenced by both the largescale effects of the Agulhas Current, a major ocean current, and the more local effects of winds and tides (Schumann, 1998, 1987). The occurrence of coastal fronts, parallel to the coastline, within this area has been described, and shown to affect the distribution of nearshore invertebrate larvae (Weidberg et al., 2019). The larvae of coastal fishes on the south coast of South Africa comprise a broad phylogenetic grouping, including a range of taxa influenced by various oceanographic conditions (Pattrick and Strydom, 2014, 2008). Due to this variability in early life history, larval fishes within the area could respond differently to their surrounding dynamic environment and may or may not use different physical features, including coastal fronts, as a means of transport to the nearshore, as suggested for the larvae of tropical reef fish (Graber and Limouzy-Paris, 1997). As an example, in a river plume system which forms a distinct frontal boundary, complex patterns of larval fish occurred, compared to offshore locations, with further investigation of species-specific fine-scale interactions suggested by the authors (Swieca et al., 2020).

The ichthyoplankton of the temperate south coast of South Africa can be divided into three coarse categories based on the distribution of the adults and the types of eggs they produce (Beckley, 1986). These categories include larvae of: (1) pelagic species with pelagic eggs (PEP), (2) coastal species with benthic eggs (COB), and (3) coastal species with pelagic eggs (COP). Seasonality also plays a clear role in determining larval fish abundances and composition in the area (Beckley, 1986; Pattrick and Strydom, 2008). In addition, larger (flexion and postflexion) larvae, with mechanisms to actively control their retention, could select preferential vertical and horizontal zones within the front. We therefore hypothesised that coastal fronts can influence the structure, including both composition and abundance, of ichthyoplankton assemblages, with the larvae of $\mathrm{COB}$ and $\mathrm{COP}$ remaining onshore of the front, while the larvae of PEP would mostly be found offshore of fronts. We examined the bio-physical interactions of larvae by concurrently measuring physical parameters of the water column and the structure of larval fish assemblages. We used a horizontally and vertically stratified sampling design within a restricted area where coastal fronts occur frequently to allow three-dimensional mapping of cross-frontal variability in both larval fish assemblages and the physical structure of the water column over multiple independent occasions of front formation. 


\section{MATERIALS AND METHODS}

\section{Study Site}

The study was carried out on the southeast coast of South Africa, off the southern shoreline of Cape Recife, Algoa Bay (Figure 1). Four frontal events located by observing foam lines or oily slicks (width 4-10 m) parallel to the shoreline (Event 1: 11/12/2014; Event 2: 17/12/2014; Event 3: 11/05/2015; and Event 4: $12 / 05 / 2015)$ were sampled from 500 to $2500 \mathrm{~m}$ offshore of Sardinia Bay $\left(34^{\circ} 2^{\prime} 11.41^{\prime \prime} \mathrm{S} ; 25^{\circ} 29^{\prime} 55.0^{\prime \prime} \mathrm{E}\right)$ between December 2014 and May 2015. For each sampling event, environmental data and ichthyoplankton samples were collected from three zones identified visually as foam lines or oily slicks (Figure 2): within the front itself (hereafter, front), $>400 \mathrm{~m}$ offshore of the front (offshore) and $>400 \mathrm{~m}$ inshore, between the front and the coast (onshore). All events occurred when wind speed was $<5.14 \mathrm{~m} / \mathrm{s}$ and swell $<1.5 \mathrm{~m}$.

\section{Field Sampling and Fish Identification}

Each frontal event was sampled during the morning (sampling each event taking $<5 \mathrm{~h}$ ) and coincided with neap tides, with predicted tidal ranges varying from 0.6 to $1 \mathrm{~m}$. The sampled fronts appeared at the coast during falling tides, thus all sampling occurred during the falling tide. During each frontal

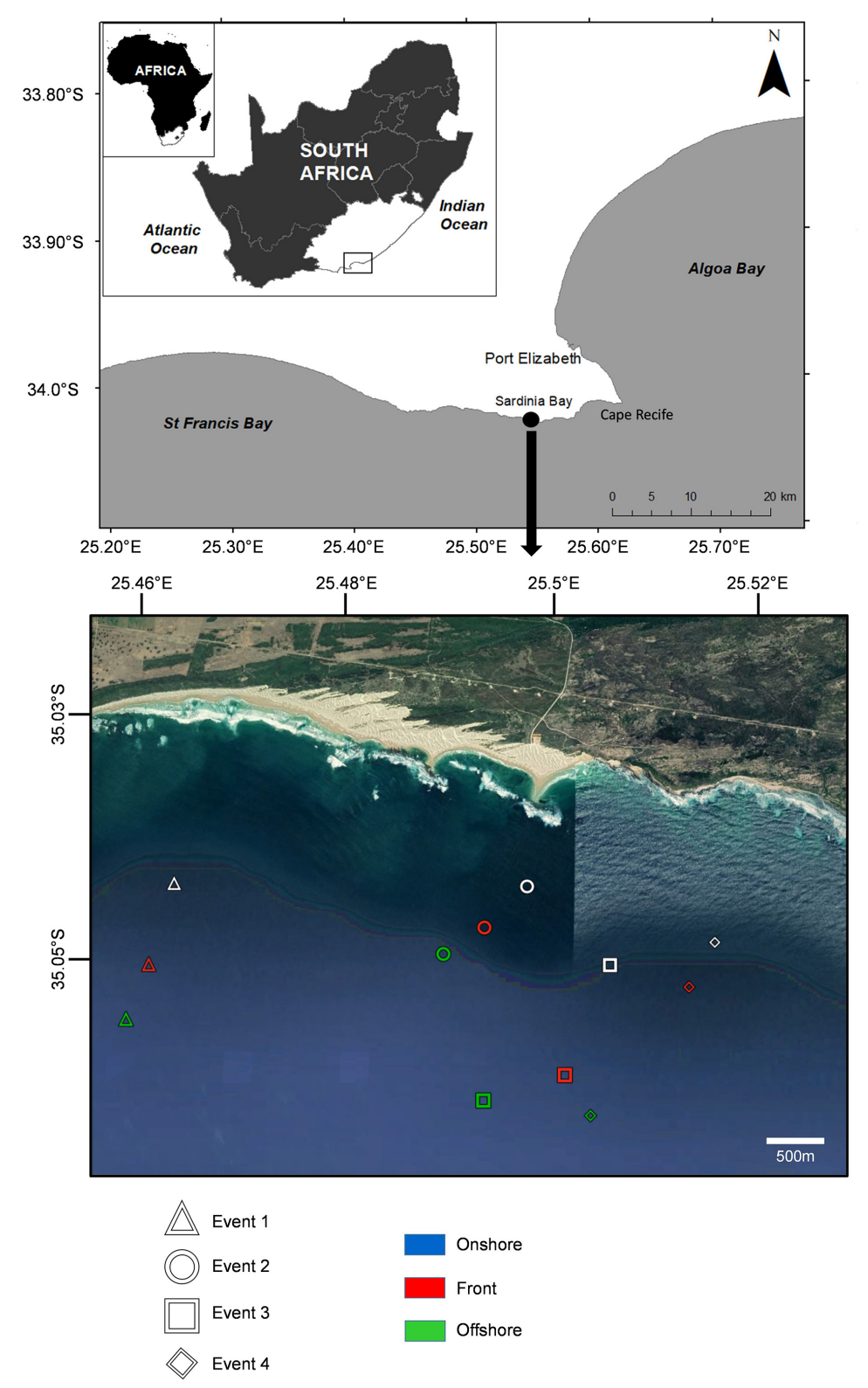

FIGURE 1 | Map of the study site, Sardinia Bay, in a high resolution Google Earth map, the nearshore location of the three sampling zones (onshore, front, and offshore) for each frontal event are shown. 


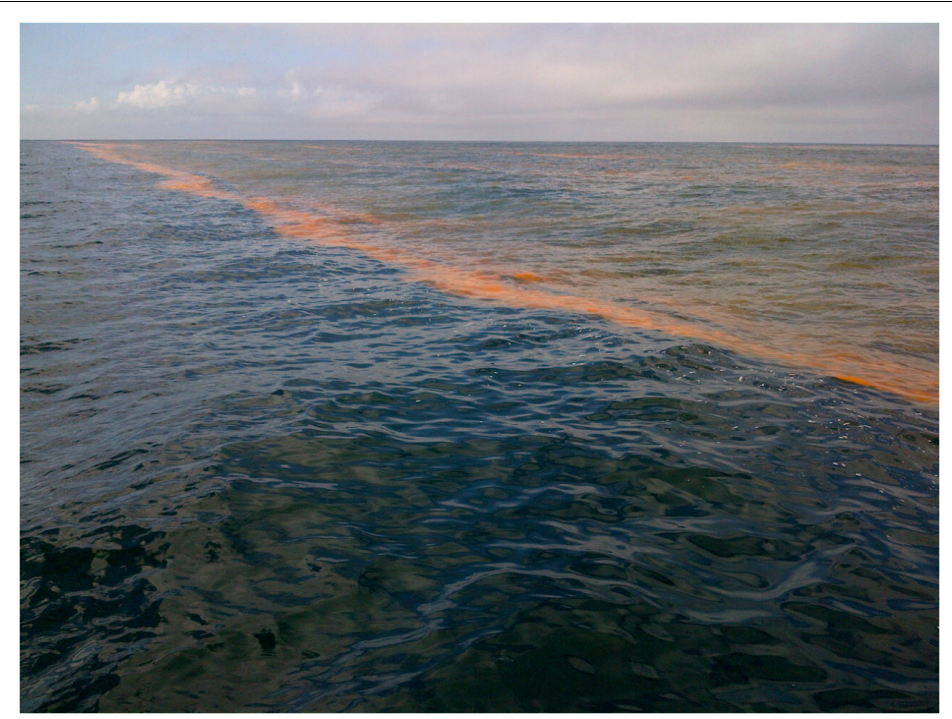

FIGURE 2 | Image of coastal front with indicative surface slick observed by the naked eye (image Paula Pattrick).

event, biological sampling from the $13 \mathrm{~m}$ research vessel, uKwabelana, in each zone (i.e., onshore, front, or offshore), was preceded by a hydrographic cast using a Seabird SBE 19 Plus conductivity-temperature-depth (CTD) profiler. Sea temperature $\left({ }^{\circ} \mathrm{C}\right)$, salinity, fluorescence $\left(\mathrm{mg} / \mathrm{m}^{3}\right)$, oxygen $(\mathrm{ml} / \mathrm{l})$, and turbidity (NTU) data were fully processed using the Seabird Seasoft software and binned to $0.5 \mathrm{~m}$ depth intervals. Following the CTD cast, a $600 \mathrm{kHz}$ acoustic Doppler current profiler (ADCP, Teledyne RD Instruments ${ }^{\circledR}$ ) was lowered alongside from the stationary vessel and used to measure zonal (Avg E/W cm/s), meridional (Avg N/S cm/s), and vertical (Avg V cm/s) current speed and direction in $1 \mathrm{~m}$ depth intervals for up to $45 \mathrm{~min}$ but never less than $30 \mathrm{~min}$. For each sampling station, the raw binary data downloaded from the ADCP were processed by Teledyne RD Instrument's BBLIST programme, and then processed further by vector averaging the currents at each depth over the period of the deployment. Ichthyoplankton samples were collected during two horizontal tows (serving as replicates) collected at the surface $(1 \mathrm{~m})$ and thereafter two horizontal tows near the bottom (onshore 10-13 m; front 13-20 m; and offshore 28-35 m) (Figure 1) in each zone using a bongonet. Replicated tows always had the same steaming direction, but different starting points. The bongo-net was designed and fabricated, by the authors for this study, with a specific closing mechanism which closed off the mouth of the net during hauling from depth when the vessel remained stationary. The bongonet had two nets with contents from each net pooled after each horizontal tow (two horizontal tows serving as two replicates for the surface and two for the bottom). A Lowrance HDS-10 Base Multifunction GPS Chartplotter was used to monitor the depth of the bongo-net. The total number of tows per frontal event were 12. The nets were $57 \mathrm{~cm}$ in diameter with a mesh size of $500 \mu \mathrm{m}$. The bongo-net was hauled along a line parallel to the front at a speed of $3.7 \mathrm{~km} / \mathrm{h}$ ( 2 knots) and each transect ran for 3 min excluding deployment time. A General Oceanics flowmeter attached to the centre of each net was used to quantify the volume of water sampled. The density of larval fishes caught per haul was expressed as the number of larvae $/ 100 \mathrm{~m}^{3}$. The plankton samples were preserved on site using $99 \%$ ethanol.

In the laboratory, larval fishes were isolated from the rest of the sample, counted, measured, and identified to the lowest possible taxon (Supplementary Table 1) (Smith and Heemstra, 1995; Neira et al., 1998; Leis and Carson-Ewart, 2000). Notochord length in preflexion and flexion larvae and standard length in postflexion larvae were measured to the nearest $0.1 \mathrm{~mm}$ and are referred to as body length $\left(L_{B}\right)$ (Supplementary Table 2). All general guidelines of the ethical use of animals in research, the legal requirements of South Africa and the guidelines of the South African Institute for Aquatic Biodiversity (SAIAB) were adhered to. This study was granted ethic clearance by the SAIAB (reference number: 2014/07).

\section{Sources of Accumulation}

To determine whether fish larvae accumulating at the front came from the onshore or the offshore regions, we followed the method of Weidberg et al. (2014), a modification of Pineda (1999). Water movement toward the front from either the offshore or the onshore zone was calculated for both the surface and the near bottom of the water column using the current data from the ADCP. Absolute current velocities $(\mu)$ were calculated for the horizontal direction perpendicular to the front for the front $\left(\mu Y_{f}\right)$, onshore $\left(\mu Y_{o n}\right)$, and offshore $\left(\mu Y_{o f f}\right)$ waters.

$$
\begin{aligned}
& \Delta \mu Y_{o n}=\mu Y_{f}-\mu Y_{o n} \\
& \Delta \mu Y_{o f f}=\mu Y_{o f f}-\mu Y_{f}
\end{aligned}
$$

From absolute current velocities, the relative velocities of offshore $\left(\Delta \mu Y_{\text {off }}\right)$ and the onshore $\left(\Delta \mu Y_{\text {on }}\right)$ waters toward the front were calculated for both the surface $(1 \mathrm{~m})$ and near bottom (onshore 10-13 m; front 13-20 m; and offshore 28-35 m) waters. 
Larval supply rates (no. larvae $/ 100 \mathrm{~m}^{3} / \mathrm{s}$ ) to the front from either the onshore $\left(S_{o n}\right)$ or from the offshore $\left(S_{\text {off }}\right)$ were calculated as:

$$
\begin{aligned}
& S_{o n}=\Delta \mu Y_{o n} \times L_{o n} \\
& S_{o f f}=\Delta \mu Y_{o f f} \times L_{o f f}
\end{aligned}
$$

where $L_{\text {on }}$ and $L_{\text {off }}$ are larval densities at the onshore and offshore zones, respectively (Weidberg et al., 2014).

\section{Larval Fish Temporal Variability and Life History Traits}

Non-parametric tests were used for the larval fish data due to the non-normality of the data. Seasonality in the abundances of fish larvae between summer (Event 1 and Event 2) and winter (Events 3 and 4) was tested using the non-parametric Wilcoxon (W) rank-sum test performed using base functions in R software v3.6.1 (R Development Core Team, 2019) for each of the three fish categories (COB, COP, and PEP) based on the distribution of the adults and the types of eggs they produce and for the total larval fish density.

A non-parametric Kruskal-Wallis (H) ANOVA was used to determine if there were any significant differences in the lengths of the larvae of the dominant fish families (Blenniidae, Cynoglossidae, Gobiesocidae, Mugilidae, and Soleidae) among the onshore, front and offshore zones.

Due to multiple testing, the false discovery rate (FDR) method of Benjamini and Hochberg (1995) was applied to control for Type I errors or false positives (Benjamini and Hochberg, 1995). Significant (based on a Q FDR of 0.05) main effects on larval density patterns were further evaluated through post hoc pairwise comparisons (Siegel-Tukey Test).

\section{Larval Fish Spatial Variability}

For each of the four frontal events, a permutational multivariate analysis of variance (PERMANOVA) was used to test the null hypothesis that there were no differences in the relative abundances of fish larvae among zones (three levels: onshore, front, and offshore) or depths (two levels: surface and bottom), using a two-factor design (zone - fixed and depth - fixed) on the Bray-Curtis distance resemblance matrix. Analyses were based on 9,999 permutation of residuals within a reduced model and Type III sums of squares (Anderson and Braak, 2003).

Differences in larval densities amongst the zones, during each of the four frontal events, were tested using non-parametric Kruskal-Wallis $(\mathrm{H})$ ANOVAs for each of the three categories of life history strategies (COB, COP, and PEP) with main effects further evaluated through a post hoc Dunn Test.

\section{Relationships Among Environmental Conditions and Larvae of Dominant Fish Families}

Principal component analysis (PCA) was performed to gain insight into which environmental variables were driving the larvae of the most abundant fish families using PRIMER v6 with the PERMANOVA + add-on. Environmental data were examined in draftsman scatter plots (Supplementary Image 1) to ascertain whether some variables were highly $\left(r^{2}=/>0.70\right)$ correlated with one another. Salinity was positively correlated with temperature $\left(r^{2}=0.76\right)$ and therefore salinity was removed from the analyses to reduce the influence of cross-correlated variables on the data. Temperature was included to serve as a surrogate for salinity (Holliday et al., 2011). After normalisation, the averages of the environmental variables for the most abundant fish families were used. Following that of Weidberg et al. (2019), PC1 and PC2 of the analysis were considered as the descriptors of the larval fish assemblage.

\section{RESULTS}

\section{Oceanographic Conditions}

Event 1 was characterised by a salinity gradient, with lower salinity in the onshore. High values of fluorescence were observed at the front (Figure 3), located about $2.25 \mathrm{~km}$ from the coastline. The front was also marked by a drop in temperature with temperatures $1^{\circ} \mathrm{C}$ higher on either side (Figure 3) and vertical velocity was stronger at the bottom than at the surface (Figure 4). Currents within the front and offshore flowed roughly parallel to the coast in an easterly direction at the bottom and a westerly direction at the surface.

During Event 2, the front was located about $1.1 \mathrm{~km}$ from the coastline and was characterised by having high fluorescence and oxygen concentration. Current speed at the bottom offshore station was substantially higher than the other positions, reaching almost $150 \mathrm{~cm} / \mathrm{s}$ in the northeastward direction at the deepest measurement, with upward vertical currents of $57 \mathrm{~cm} / \mathrm{s}$ (Figure 4). In the surface layers of the offshore zone, current flowed westward with slower velocities $(35 \mathrm{~cm} / \mathrm{s})$ and vertical upward currents were similarly substantially slower $(0.2 \mathrm{~cm} / \mathrm{s})$. Thus, a change in flow direction with different depth layers was also observed during Event 2.

During Event 3, temperature defined the front, which was located about $2.75 \mathrm{~km}$ from the coastline. The surface waters were warmer and more oxygenated than the bottom waters. Turbidity was higher in the onshore, particularly at the bottom of the water column. During Event 3, weak offshore currents $(\sim 8 \mathrm{~cm} / \mathrm{s})$ were observed in the bottom waters of the onshore zone, while slower alongshore currents $(\sim 4 \mathrm{~cm} / \mathrm{s})$ were found at the surface (Figure 4). Within the front zone, weak $(<6 \mathrm{~cm} / \mathrm{s})$ offshore currents were observed in both the surface and bottom layers. In the offshore zone, strong westward $(38 \mathrm{~cm} / \mathrm{s})$ alongshore currents were observed in the surface waters with weaker westward $(8 \mathrm{~cm} / \mathrm{s})$ alongshore currents observed at the bottom (Figure 4).

During Event 4, the front was located about $2 \mathrm{~km}$ from the coastline (Figure 3). A slower southwestward alongshore current of $<10 \mathrm{~cm} / \mathrm{s}$ was observed in the bottom of the water column, while faster westward alongshore currents in the surface layers $(>25 \mathrm{~cm} / \mathrm{s})$.

\section{Accumulation Patterns}

In the surface layer, positive relative accumulation velocities indicating convergence and potential accumulation were observed from the onshore side (positive $\Delta \mu Y_{\text {on }}$ ) during Events 1 and 4 and from the offshore (positive $\Delta \mu Y_{\text {off }}$ ) 

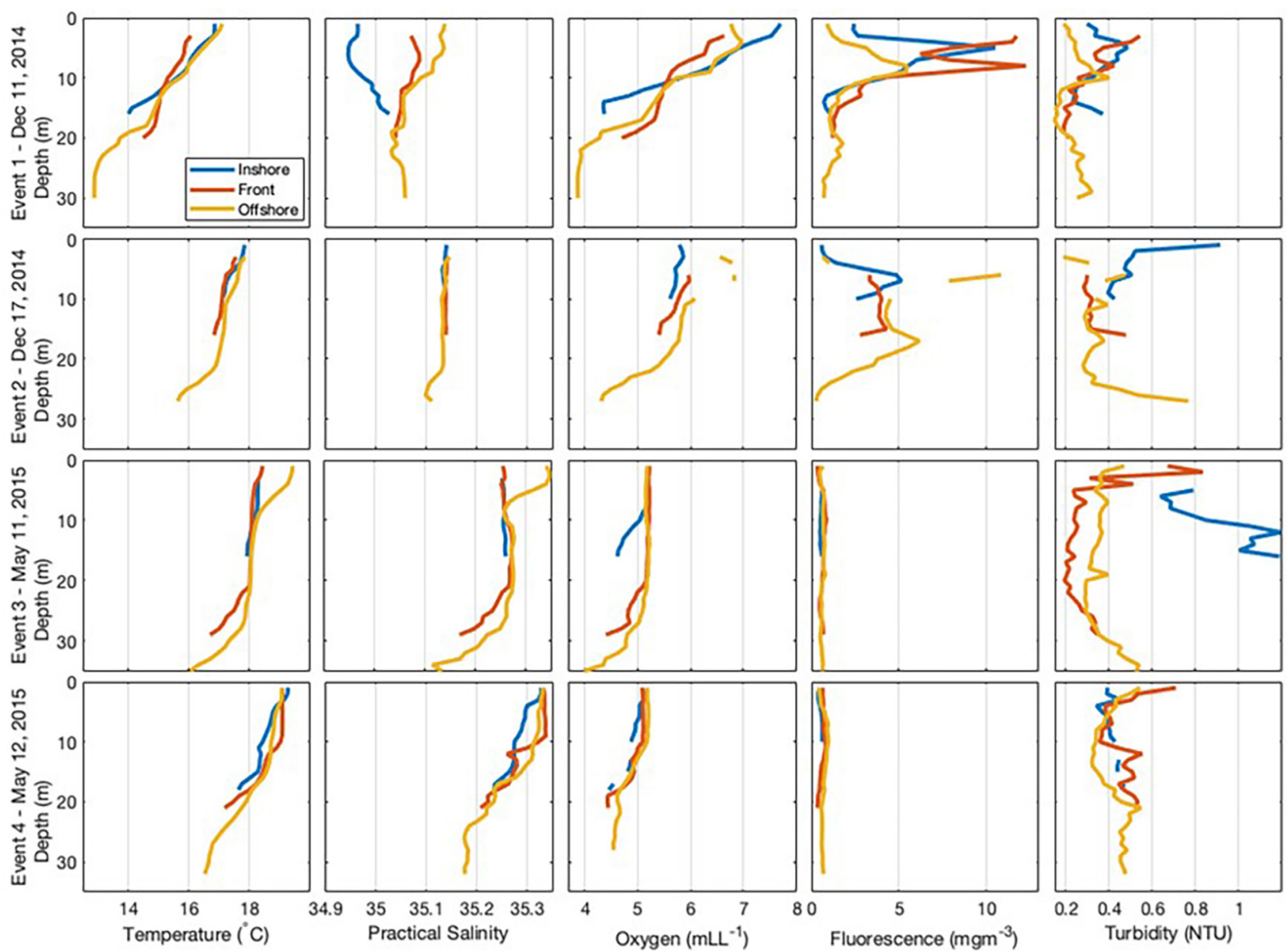

FIGURE 3 | Cross-shore transect for each frontal event showing vertical sections of temperature, salinity, oxygen, fluorescence, and turbidity recorded at each zone within the coastal nearshore of Sardinia Bay region during December 2014-May 2015.

during Events 2 and 3. At the bottom, positive convergent speeds from the onshore occurred only during Event 3, while during the other events waters converged to the front from the offshore side (Table 1). During Event 1, the source of larvae of $\mathrm{COB}$ at surface frontal waters was onshore, while COP accumulated from the offshore at the bottom (Table 2). During Event 2, COB and COP aggregated from the offshore side of the front both at the surface and at the bottom, while the source of PEP could only be inferred at the surface and it was also offshore. At Event 3, COB and COP at the front were advected from offshore waters at the surface and from onshore waters at the bottom, while PEP also came from the onshore at the bottom. During Event 4, all species shared the same source, which was onshore at the surface and offshore at the bottom.

\section{Larval Fish Species Composition, Seasonality, and Life History}

Larval fishes collected (Table 3) over the entire sampling campaign $\left(n_{\text {total }}=807 ; n_{\text {onshore }}=356 ; n_{\text {front }}=218\right.$; $n_{\text {offshore }}=233$ ) represented 21 fish families ( $n_{\text {onshore }}=16$; $\left.n_{\text {front }}=11 ; n_{\text {offshore }}=18\right)$ and 39 species $\left(n_{\text {onshore }}=22\right.$; $\left.n_{\text {front }}=22 ; n_{\text {offshore }}=29\right)$. On all occasion, each recorded taxon was numerically dominated by a singles species. The Cynoglossidae (COP) dominated overall catches and numerically was represented almost entirely by Cynoglossus capensis (96.5\% of Cynoglossidae family composition). Other abundant fish families included the Soleidae, dominated by Heteromycteris capensis (98.7\%), Mugillidae, dominated by an unidentified species (94.9\%), Gobiesocidae, dominated by Diplecogaster megalops (93.3\%), Clupeidae, dominated by Etrumeus whiteheadi (86.0\%) and Blenniidae, dominated by Parablennius pilicornis (61.3\%). The Cynoglossidae comprised $42.2 \%$ of individuals in offshore samples, $13.4 \%$ in the front and $11.0 \%$ in the onshore region. Offshore, Soleidae (COP) $(15.1 \%)$, Mugillidae (COP) (10.8\%), and Blenniidae (COP) (8.2\%) also contributed to larval fish catches. In the front itself, Mugillidae (39.4\%) dominated catches, with a substantial presence of Blenniidae (19.0\%) and Soleidae (8.8\%). The Soleidae (26.8\%), Gobiesocidae (COB) (26.2\%), and the Clupeidae (PEP) (12.7\%) dominated catches in the onshore region. The COP dominated overall catches comprising 59\%, with the COB contributing $33 \%$ toward the overall catch and the PEP contributing only $8 \%$. 

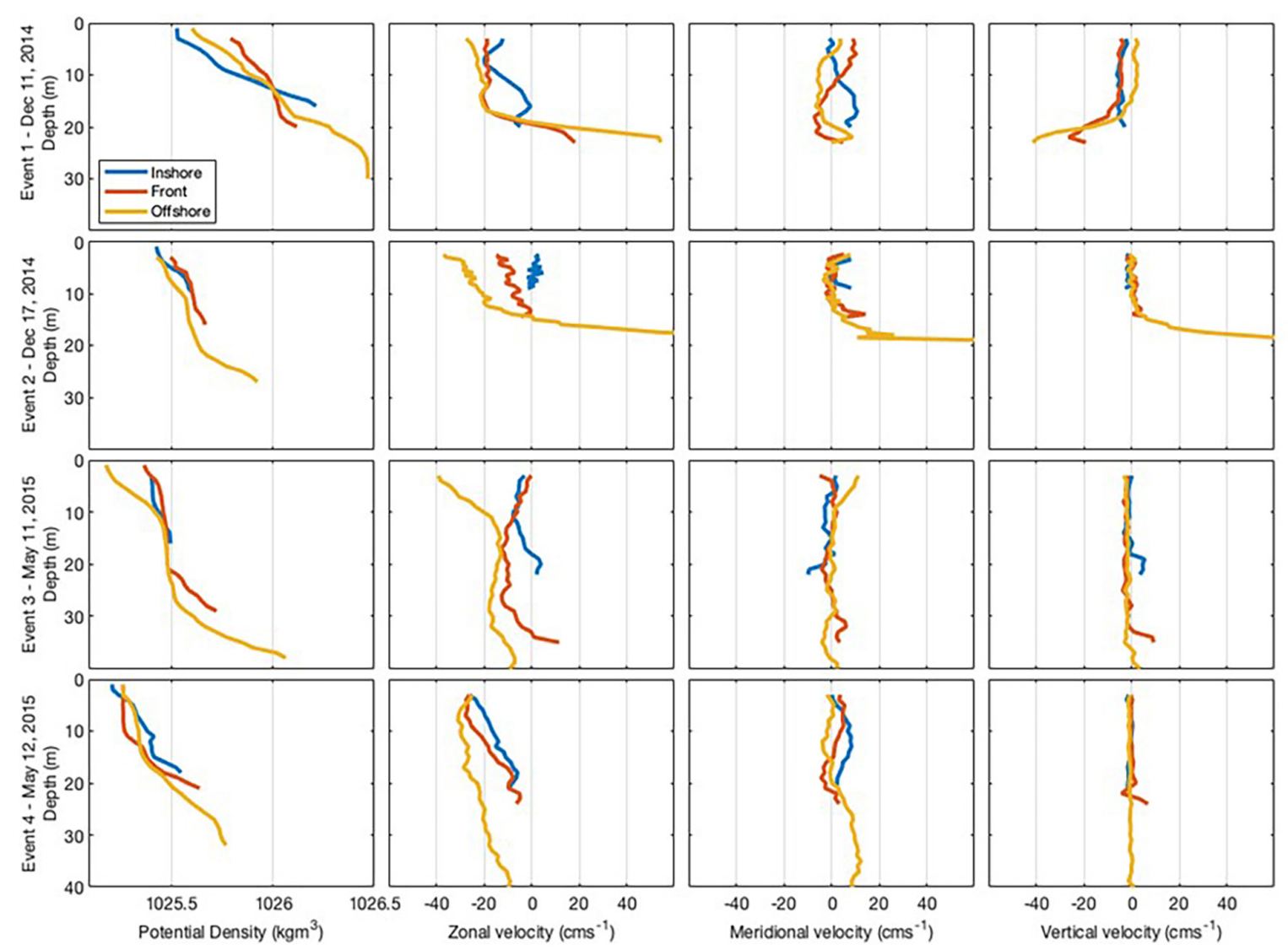

FIGURE 4 | Cross-shore transect for each frontal event showing vertical sections of density, zonal, meridional, and vertical current velocity recorded at each zone within the coastal nearshore of Sardinia Bay region during December 2014-May 2015. Sardinia Bay runs approximately east-west, thus zonal currents are alongshore, with positive values eastward and negative values westward. Meridional currents are across-shore, with positive values northward (toward the coast) and negative values eastward (away from the coast). Positive vertical currents are toward the surface and negative vertical currents are away from the surface.

Preflexion larvae comprised roughly $50 \%$ of the larval fish catch and larvae in the flexion stage of development contributed $36.6 \%$ to the total catch with $10.2 \%$ of the total catch consisting of postflexion larvae.

Significantly $(W=81.0 ; p<0.001)$ more larvae were recorded during the winter (mean 5.2 larvae/100 $\mathrm{m}^{3}$ ) than summer (mean

TABLE 1 | Mean $( \pm S D)$ absolute $(\mu)$ and relative $(\Delta \mu)$ velocities $(\mathrm{cm} / \mathrm{s})$ of surface and bottom waters moving perpendicular $(Y)$ to the front.

\begin{tabular}{lccccrr}
\hline & & $\boldsymbol{\mu} \boldsymbol{Y}_{\text {on }}$ & $\boldsymbol{\mu} \boldsymbol{Y}_{\boldsymbol{f}}$ & $\boldsymbol{\mu} \boldsymbol{Y}_{\text {off }}$ & $\boldsymbol{\Delta} \boldsymbol{\mu} \boldsymbol{Y}_{\text {on }}$ & $\boldsymbol{\Delta} \boldsymbol{\mu} \boldsymbol{Y}_{\text {off }}$ \\
\hline Event 1 & Surface & $-0.7 \pm 1.9$ & $9.0 \pm 0.6$ & $3.2 \pm 0.7$ & 9.7 & -5.8 \\
& Bottom & $7.9 \pm 1.1$ & $-1.6 \pm 5.9$ & $4.8 \pm 4.5$ & -9.5 & 6.4 \\
Event 2 & Surface & $4.5 \pm 3.3$ & $1.3 \pm 3.6$ & $5.4 \pm 2.5$ & -3.2 & 4.1 \\
& Bottom & $4.9 \pm 3.5$ & $9.3 \pm 4.3$ & $33.9 \pm 27.9$ & 4.4 & 24.6 \\
Event 3 & Surface & $1.7 \pm 0.5$ & $-1.6 \pm 3.1$ & $10.2 \pm 0.9$ & -3.3 & 11.8 \\
& Bottom & $-7.4 \pm 4.2$ & $2.6 \pm 0.7$ & $1.3 \pm 1.8$ & 10.0 & -1.3 \\
Event 4 & Surface & $0.8 \pm 0.9$ & $4.0 \pm 1.2$ & $-0.5 \pm 1.5$ & 3.2 & -4.5 \\
& Bottom & $2.4 \pm 0.6$ & $2.2 \pm 0.9$ & $8.8 \pm 0.4$ & -0.2 & 6.6
\end{tabular}

Velocities were recorded on the onshore (on), at the front ( $f$ ), and on the offshore side (off). A positive value indicates a northward (onshore) direction on the $Y$ axis.
1.0 larvae $/ 100 \mathrm{~m}^{3}$ ) sampling. This trend was particularly true for the COP (winter mean 3.4 larvae $/ 100 \mathrm{~m}^{3}$; summer mean 0.2 larvae $/ 100 \mathrm{~m}^{3} ; W=35.0 ; p<0.001$ ) and PEP (winter mean 0.4 larvae $/ 100 \mathrm{~m}^{3}$; summer mean 0.1 larvae $/ 100 \mathrm{~m}^{3}$; $W=195.0 ; p<0.05)$. Although more COB larvae were captured during the winter period, the difference between seasons was not

TABLE 2 | The source of accumulating larvae at the surface and the bottom of the frontal waters during the four different frontal events.

\begin{tabular}{cccccc}
\hline & & Event 1 & Event 2 & Event 3 & Event 4 \\
\hline Surface & Total Density & Onshore & Offshore & Offshore & Onshore \\
& COB & Onshore & Offshore & Offshore & Onshore \\
& COP & $\mathrm{n} / \mathrm{a}$ & Offshore & Offshore & Onshore \\
& $\mathrm{PEP}$ & $\mathrm{n} / \mathrm{a}$ & Offshore & $\mathrm{n} / \mathrm{a}$ & Onshore \\
\multirow{4}{*}{ Bottom } & Total Density & Offshore & Offshore & Onshore & Offshore \\
& COB & $\mathrm{n} / \mathrm{a}$ & Offshore & Onshore & Offshore \\
& COP & Offshore & Offshore & Onshore & Offshore \\
& PEP & Offshore & n/a & Onshore & Offshore \\
\hline
\end{tabular}

n/a $=$ not applicable 
TABLE 3 | Species composition by number $(N)$ and as a percentage of total catch $\left(\% \sum N\right)$, mean body length $\left(L_{B}\right)$, and developmental stage (Pr, preflexion; $F$, flexion; $\operatorname{Po,}$ postflexion) of larval fishes caught by bongo net in the nearshore surface slicks in Sardinia Bay.

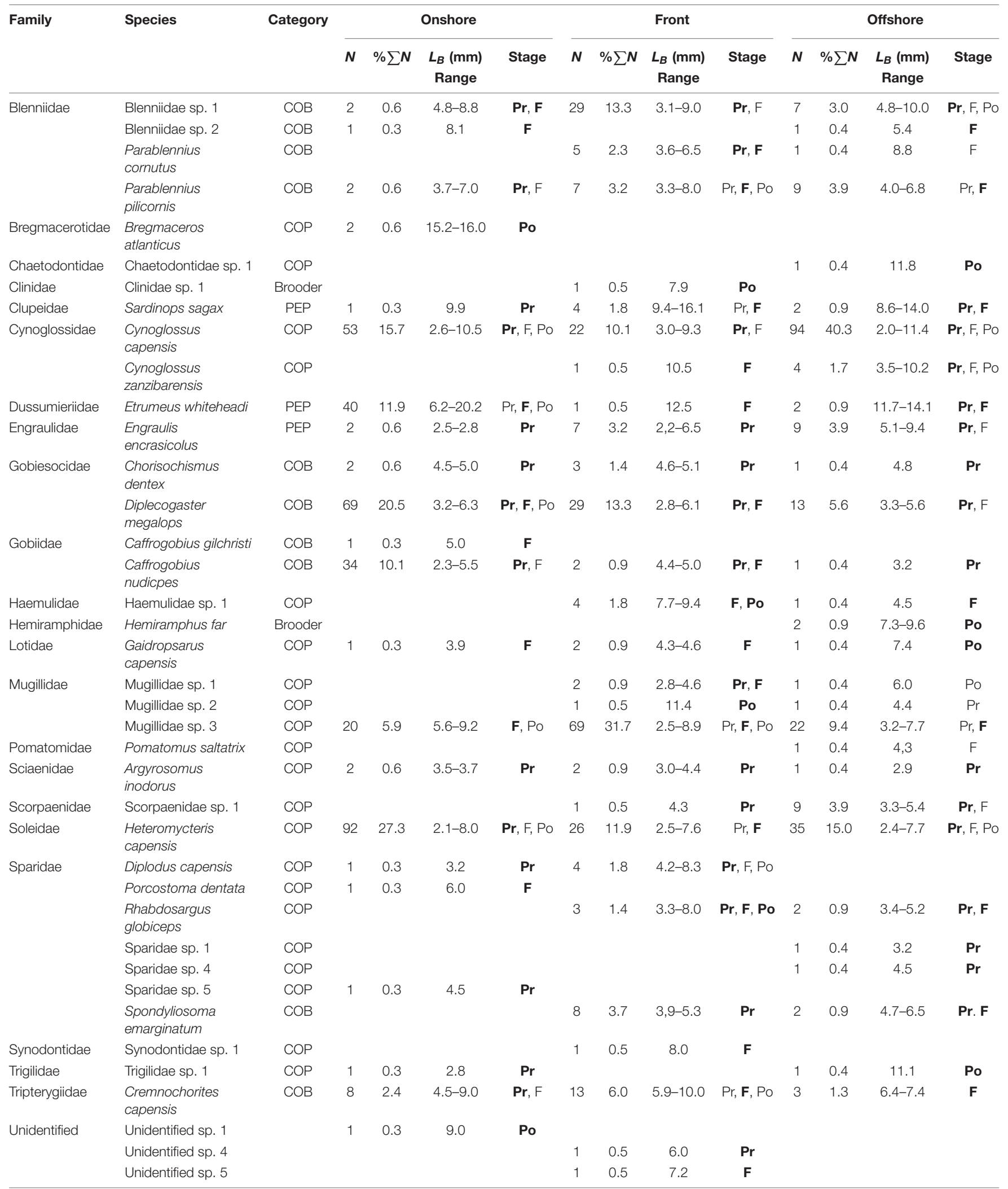

Dominant developmental stages are in bold. 
significant (winter mean 1.3 larvae/100 $\mathrm{m}^{3}$; summer mean 0.7 larvae $/ 100 \mathrm{~m}^{3} ; W=270.5 ; p=0.72$ ).

Fish larvae of the dominant taxonomic groups differed significantly in size (length) at different positions with respect to the fronts. Large sized Soleidae $(H=11.26$; $\mathrm{df}=2 ; p<0.01$; Dunn test $=3.3)$ and Gobiidae $(H=3.52 ; \mathrm{df}=2 ; p=0.17)$ larvae occurred predominantly at the front (Table 3). Small-sized Blenniidae $(H=7.99$; $\mathrm{df}=2 ; p<0.05$; Dunn test $=-2.3)$, Cynoglossidae $(H=0.89 ; \mathrm{df}=2 ; p=0.64)$, and Mugilidae $(H=9.22 ; \mathrm{df}=2 ; p<0.001$; Dunn test $=-3.0)$ larvae occurred at the front. Large Blenniidae, Gobiesocidae $(H=1.80 ; \mathrm{df}=2$; $p=0.41)$ and Mugilidae larvae occurred in the onshore.

\section{Spatial Trends in Larval Fishes}

The outcome of the PERMANOVA tests on total larval fishes run individually for each frontal event (Table 4) revealed high variability at the levels of both zone and depth (excluding zone at Event 3). Higher mean densities of fish larvae were observed in the front during Event $1(H=4.77 ; \mathrm{df}=2 ; p=0.09)$, onshore during Event $4(H=0.15 ; \mathrm{df}=2 ; p=0.93)$, and offshore during Event $2(H=7.14$; $\mathrm{df}=2 ; p<0.05)$ than during the rest of the sampling. During Event 4, the interaction between zone and depth was highly significant (Table 4), with highest densities being observed in the onshore bottom layers.

The composition of the larval fish assemblage and the spatial distribution of larvae in relation to the fronts differed among the four frontal events. COB accumulated onshore during Events 1 $(H=8.12 ; \mathrm{df}=2 ; p<0.05), 3(H=0.73 ; \mathrm{df}=2 ; p=0.69)$ and $4(H=0.81 ; \mathrm{df}=2 ; p=0.67)$ (Figure 5). During Event 2, COB $(H=7.54 ; \mathrm{df}=2 ; p<0.05)$ and $\mathrm{COP}(H=8.12 ; \mathrm{df}=2 ; p<0.05)$ accumulated significantly in the offshore. COP accumulated at the front during Event $1(H=8.12$; df $=2 ; p<0.05)$ and Event $3(H=0.73$; df $=2 ; p=0.69)$. No specific pattern in PEP was observed with accumulation in the offshore during Event 1 $(H=2.00 ; \mathrm{df}=2 ; p=0.37)$, at the front during Event $2(H=0.07$; $\mathrm{df}=2 ; p=0.97)$ and onshore during Event $3(H=4.02 ; \mathrm{df}=2$; $p=0.13)$ and Event $4(H=4.83 ; \mathrm{df}=2 ; p=0.10)$.

\section{Dominant Fish Family Analysis and Environmental Correlation}

The PCA multivariate analysis using environmental variables within the zones and their relationships with the distribution of the dominant larval fish families showed that PC1 explained $44.5 \%$ of the total variability of the data (Figure 6 and Table 5).
The greatest loadings on PC1 being meridional flow followed by zonal flow. Haemulidae larvae were most influenced by offshore (south) meridional flow while Sparidae and Cynoglossidae larvae were influenced by onshore (north) meridional flow. PC2 explained a lower percentage of variability $(27.3 \%)$ and was driven by dissolved oxygen and fluorescence. Sparidae and Blenniidae larvae were mostly influenced by higher levels of fluorescence and oxygen.

\section{DISCUSSION}

Our findings highlight the important contributions that life history traits and hydrodynamics play in larval transport and coastal retention associated with fronts. Specifically, four different fronts were sampled during austral summer (2014) and winter (2015), during falling neap tides, and the data analysed separately to identify common trends. Owing to the sampling design adopted for this study, with measurements within each event, serving as independent replicates, the strength of the analysis lies in the description of each event separately.

During this study, each frontal event was characterised by different hydrological and physical conditions. Surface slicks are associated with one or a combination of wind-driven, buoyancy, topographic or tidally generated physical forcing mechanisms and are often interpreted as propagating features associated with internal waves (Franks, 1992a; Leichter et al., 1998; McCulloch and Shanks, 2003; Shanks et al., 2003). Previous research within the same study region suggested that these fronts are formed by internal waves (Weidberg et al., 2019) and appeared to follow the predictions of Pineda's (1994) two-phase model for cross-shore internal tidal bores. The first phase occurs when a cold water bore is advected shoreward with warmer, lighter waters displaced offshore, resulting in a front at the surface separating water types of different temperatures, and an imbalance in hydrostatic pressure. In our study, the direction of currents moved in opposite directions, supporting Pineda's (1994) two-phase model. The frontal events observed by Weidberg et al. (2019) in the same study area, indicate how invertebrate larval assemblages changed in time together with water circulation, following the tidal cycle. Thus, it is possible that larval fish distributions changed on similar time scales. The dynamics in the nearshore circulation of the present study resulted in contrasting accumulation patterns of fish larvae at the surface and bottom layers with the different

TABLE 4 | Results of the PERMANOVA conducted on square-root transformed abundance data of fish larvae recorded in the shallow nearshore of Sardinia Bay during the four different frontal events.

\begin{tabular}{|c|c|c|c|c|c|c|c|c|c|}
\hline \multirow[t]{2}{*}{ Source } & \multirow[t]{2}{*}{ df } & \multicolumn{2}{|c|}{ Event 1} & \multicolumn{2}{|c|}{ Event 2} & \multicolumn{2}{|c|}{ Event 3} & \multicolumn{2}{|c|}{ Event 4} \\
\hline & & MS & $\boldsymbol{F}$ & MS & $\boldsymbol{F}$ & MS & $\boldsymbol{F}$ & MS & $\boldsymbol{F}$ \\
\hline Zone & 2 & 2628.1 & $3.2^{*}$ & 1985.0 & $2.5^{\star}$ & 2276.6 & 1.9 & 2553.8 & $2.5^{\star}$ \\
\hline Depth & 1 & 2389.4 & $2.9^{\star}$ & 2416.3 & $3.1^{*}$ & 6600.6 & $5.5^{\star}$ & 4839.3 & $4.7^{\star}$ \\
\hline Zone $\times$ depth & 2 & 714.5 & 0.9 & 1078.2 & 1.4 & 1542.2 & 1.3 & 3224.9 & $3.2^{* *}$ \\
\hline Res & 6 & 820.8 & & 788.0 & & 1198.1 & & 1020.1 & \\
\hline Total & 11 & & & & & & & & \\
\hline
\end{tabular}

${ }^{*} p<0.05 ;{ }^{* *} p<0.01 ; d f=$ degree of freedom; $M S=$ mean sum of squares; $F=F$-value by permutation. 


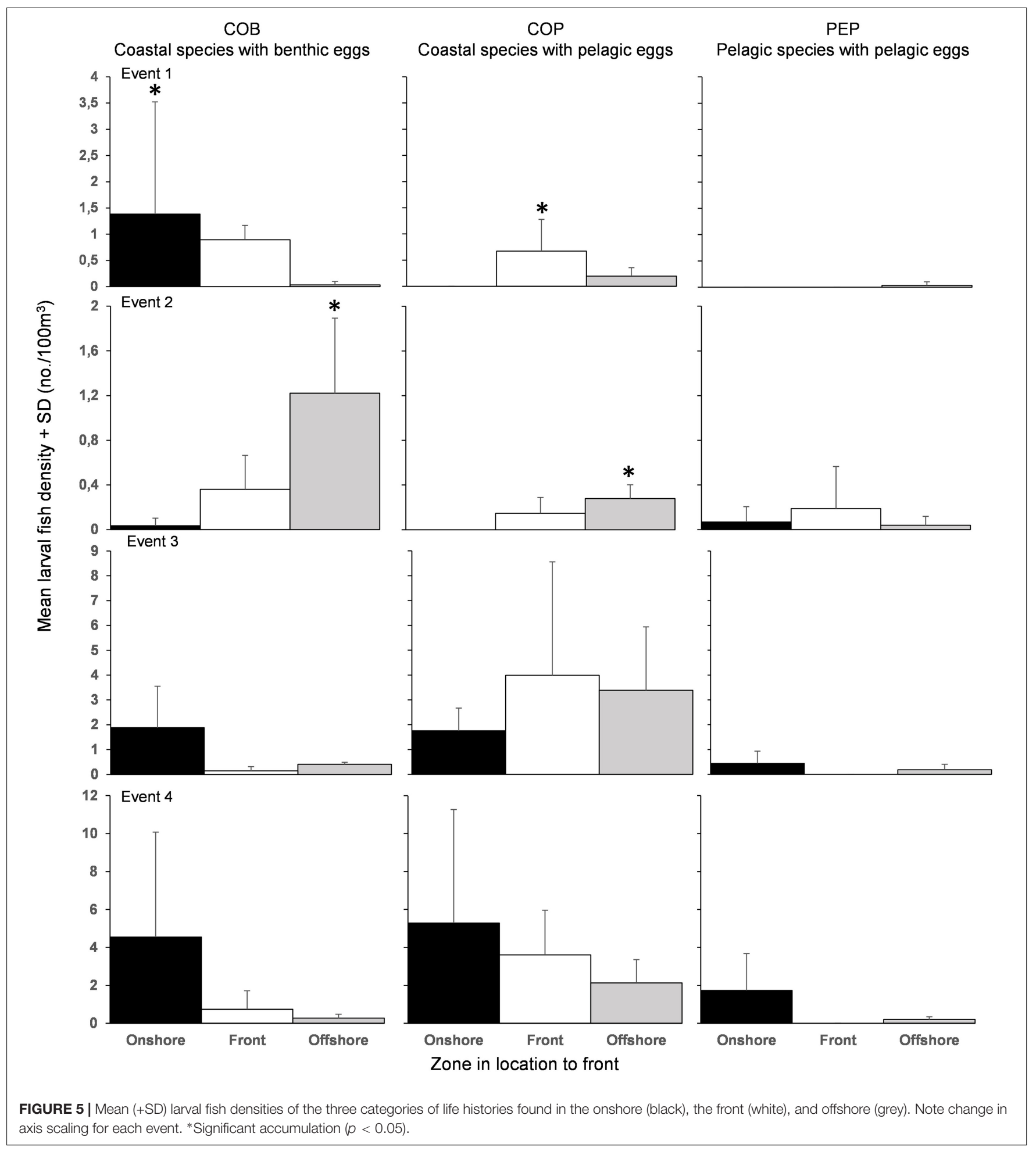

life history categories showing specific zone association to the frontal systems.

Within the frontal zone, the vertical distribution of larvae was species specific, as has been observed in internal waves in other coastal habitats (Greer et al., 2014). Larvae of the COP Mugillidae and Sparidae, almost always dominated surface waters. The prevalence of mugillid and sparid larvae in ichthyoplankton tows in slicks has been previously documented, with ephemeral prevalence at the surface (Kingsford and Choat, 1986; Rissik and Suthers, 1996). During Event 3, flexion Mugillidae occurred exclusively in the surface layers of the front zone, with the source of accumulating larvae being from the offshore. A significant 


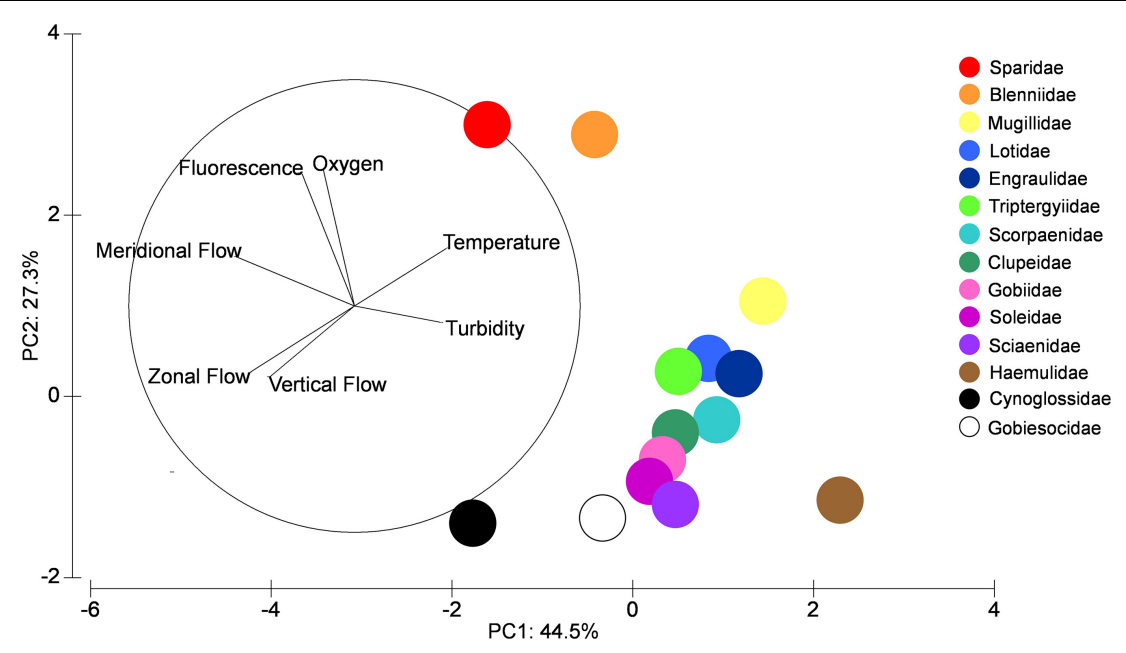

FIGURE 6 | PCA analysis showing percentage variability for each PC axis for larval fish families for all samples during the four frontal events within the coastal nearshore of Sardinia Bay region during the study (December 2014-May 2015).

accumulation of Mugillidae (co-occurrence of all developmental stages) at the front zone during Event 4 was also observed, but the source then was the onshore region. With large larvae occurring onshore, these larvae could potentially be moving inshore from offshore spawning areas, toward their juvenile nursery areas using the mechanisms of the coastal fronts. The shoreward progression of larval reef fish in fronts supports the supply of competent larvae to their reef settlement habitat (Woodson et al., 2012). During Event 1, Sparidae larvae occurring at the surface of the front zone were associated with fluorescence according to the PCA. Fluorescence can be considered as a proxy for chlorophyll- $a$ and in the upwelling region of the Senegalese coast, highest chlorophyll- $a$ concentrations were observed in the inshore upwelling front habitat which coincided with the highest larval Sparidae densities (Tiedemann and Brehmer, 2017). Recent evidence of slicks serving as nursery areas for fish larvae have indicated that older, larger larvae that are competent swimmers are actively seeking out surface slicks in search of prey and shelter from predators (Whitney et al., 2021). This increased predator-prey overlap has been found to enhance coastal ecosystem and fisheries productivity (Woodson and Litvin, 2015; Woodson, 2018).

TABLE 5 | Results of the principal component analysis (PCA).

\begin{tabular}{lcc}
\hline Variables & PC1 & PC2 \\
\hline Temperature & $\mathbf{0 . 4 0 8}$ & -0.255 \\
Fluorescence & -0.232 & $\mathbf{0 . 5 8 4}$ \\
Oxygen & -0.137 & $\mathbf{0 . 6 0 0}$ \\
Turbidity & 0.378 & 0.071 \\
Zonal flow & $-\mathbf{0 . 4 6 1}$ & 0.292 \\
Meridional flow & $-\mathbf{0 . 5 1 5}$ & -0.214 \\
Vertical flow & -0.374 & 0.313 \\
\hline Eigenvectors (correlations) for each environmental factor (values greater than \\
O.4 are in bold).
\end{tabular}

In the surface waters during all frontal events, regardless of position in relation to the front itself (i.e., onshore, front, and offshore), on 11 out of 12 times (three regions, four events), onshore currents persisted and on seven of these occasions currents were $>20 \mathrm{~cm} / \mathrm{s}$, but $<40 \mathrm{~cm} / \mathrm{s}$. In the bottom waters, regardless of the position in relation to the frontal systems, onshore currents persisted nine out of 12 times, and only twice were the currents $>20 \mathrm{~cm} / \mathrm{s}$. Stable conditions within the nearshore environment renders this area a suitable habitat for retention and recruitment of coastal larvae (Paris et al., 2002). Larvae of coastal species hatching from either benthic (COB) or pelagic (COP) eggs were found to occur predominantly either in the onshore zone or at the front. The abundance of Blenniidae (COB) and Gobiesocidae (COB) larvae has been suggested to decrease with increasing distance from shore, due to the absence of passive drift during the demersal egg phase (Leis and Miller, 1976; Marliave, 1986; Kingsford and Choat, 1989; Suthers and Frank, 1991; Brogan, 1994). Gobiesocidae and Blenniidae larvae do, however, hatch with functional eyes, developed fins and some positive active swimming toward light (Villegas-Ríos et al., 2009). This advanced stage of morphological development upon hatching, could allow larvae to switch vertical position as the flow directions change (Breitburg et al., 1995) and actively seek out the shallower inshore. Such behavioural and developmental capabilities, which often limit larval dispersal in coastal areas (Paris and Cowen, 2004), could also apply to the surveyed frontal systems and promote retention close to the sea floor, where these eggs develop. It therefore appears that coastal frontal systems play a pivotal role in allowing the larvae of the COB species to retain themselves within the nearshore. The co-occurrence of all developmental stages (preflexion, flexion, and postflexion) within plankton samples as well as the limited area of the onshore zone also suggests retention (Stephenson et al., 2015) as observed for other taxa (Morgan et al., 2018; Roura et al., 2019). The physical structure of these coastal fronts therefore provides favourable conditions for short larval development, and plays a major role 
in reducing transport, increasing settlement and maintaining retention of larvae from these $\mathrm{COB}$ within nearshore waters.

The bottom of the offshore zone during Event 2 was characterised by a strong onshore current reaching almost $150 \mathrm{~cm} / \mathrm{s}$ and upward vertical currents of $57 \mathrm{~cm} / \mathrm{s}$, indicative of shoaling and breaking of internal waves (Aghsaee et al., 2010; Richards et al., 2013). In the surface layers of the offshore zone, current velocities were considerably slower $(35 \mathrm{~cm} / \mathrm{s})$, although still relatively strong, with upward currents also substantially weaker $(0.2 \mathrm{~cm} / \mathrm{s})$. During these turbulent strong current conditions however, accumulation of the larvae of $\mathrm{COB}$ and $\mathrm{COP}$ occurred in the offshore zone, highlighting the fact that the front is serving as a barrier for onshore advection potentially, through wider larval dispersal increasing population proliferation, which has important implications for population connectivity.

For PEP, no clear pattern was observed, with offshore accumulation during Event 1, accumulation of larvae at the front during strong turbulent current conditions (Event 2) and onshore accumulation of larvae during Events 3 and 4. The larval catches of PEP were substantially lower than those observed within a similar study area during previous surveys (Beckley, 1986; Pattrick and Strydom, 2008), however, PEP were generally found to occur in higher densities further offshore than shallow sites just behind the surf zone (Pattrick and Strydom, 2008). For PEP, perhaps other underlying physical and biological mechanisms influence their larval dispersal and retention. The seasonality observed during the present study could mainly be attributed to higher abundances of PEP occurring during winter (Event 3 and Event 4), although the peak occurrence of the larvae of PEP is known to occur in spring in this region (Pattrick and Strydom, 2008). It has been noted that defining the dispersal and habitat for larvae with pelagic adults is difficult and hence this important detail has often been omitted from analyses (Bradbury and Snelgrove, 2001).

Changes in current direction and velocity between different depth strata were often observed. These shifts would result not only in crosshore advection but also in alongshore transport in either direction. Cynoglossids, tripterygiids, and gobiesocids dominated at the bottom while the blenniids and sparids dominated at the surface. By occupying different depths in the water column, even for short periods of time, different larvae will generally experience transport in different directions. Within the region, spawning occurs all year round for these families, but with seasonal peaks, depending on the species (Pattrick and Strydom, 2008, 2014). Such multiple spawning, coupled with active selection of preferred depths by the larvae, may be a form of bet-hedging (Shanks and Eckert, 2005), with larvae from certain batches experiencing a particular alongshore transport, while other batches experience transport in other directions. Variability in alongshore transport could therefore lead to differences among the species in population connectivity (Shanks and Pfister, 2009). Indeed it has been shown that the roles that fronts can play are important to understanding the reproductive strategies of local marine populations (Acha et al., 2004). During Event 3, within the front itself, surface strata flowed in a southwestward direction and bottom strata flowed in the southeastward direction, and again, due to the orientation of the coastline, this would result in offshore transport in both cases. Larval assemblages were dominated by mugillids at the surface and by cynoglossids, gobiesocids, gobies and soles at the bottom. Studies have found that the larvae of nearshore demersal spawning fishes, including gobiesocids and gobies, are usually found close to shore (Marliave, 1986; Kingsford and Choat, 1989), near the bottom (Shanks and Eckert, 2005) and swimming against the current to maintain a fixed position (Kingsford and Choat, 1989). For these larvae therefore, despite the offshore current at the front, residing near the bottom, where current velocities were slow $(<6 \mathrm{~cm} / \mathrm{s})$ and swimming against the flow is possible, would decrease their dispersal distances. Using this recorded mechanism of nearshore retention would reduce mortality and increase coastal retention in species with short PLDs as found in the Mugillidae, Cynoglossidae, and Soleidae.

During Event 2, within the onshore zone, all larvae occurred exclusively in the surface layers where an onshore $(\mathrm{N})$ current prevailed, with larvae appearing actively to avoid the offshore (S) bottom currents, where no larvae were captured. During Event 3 , within the onshore zone, larval assemblages in the surface of the water column, where currents flowed in an onshore $(\mathrm{N})$ direction, were dominated by species of Mugillidae. Meanwhile, larval assemblages in the bottom layers where currents flowed in an offshore (S) direction, were dominated by cynoglossids and haemulids. According to the PCA, Haemulidae larvae were mostly influenced by these meridional currents. The presence of large (flexion and postflexion) larvae in the onshore at the bottom of the water column, further supports the idea that haemulid larvae remain in the nearshore throughout their larval development (Sponaugle et al., 2003), with mechanisms to control their retention actively, despite the presence of offshore currents. Fish larvae often show aggregated distributions in both horizontal and vertical dimensions within large scale oceanic frontal systems (Lough and Manning, 2001; Lee et al., 2005) and have been found to position themselves at mid-depth levels with onshore current directions (Cowen and Castro, 1994). Such offshore flow avoidance and general association with a body of water that is moving in an onshore direction, is a low cost means of transport (Shanks, 1983; Norcross and Shaw, 1984; Kingsford and Choat, 1986; Kingsford, 1988, 1990; Leis, 1991b). By actively selecting a favourable vertical position in the water column where flow is retentive, larvae can utilise coastal fronts to enhance local accumulation where conditions are likely to retain them close to shore even during advective conditions.

When currents flowed in the same direction at the surface and the bottom of the water column (evident in the onshore of Events 1 and 4), larvae tended to accumulate in the slower waters. During Event 1, abundances of gobiesocid larval were considerably higher in the bottom of the water column, where current velocities slowed down compared to the surface. During Event 4, Gobiidae larval abundances were higher at the bottom of the water column, where current velocities were less than half the velocities observed within the surface layers of the water column. Larvae of the naked goby (Gobiosoma bosc) actively aggregate and select low-flow microhabitats and can shift their position with changing flow directions (Breitburg et al., 1995). This particular behaviour has the advantage of allowing pre-settlement larvae 
such as the gobiesocids and gobies, which utilise benthic habitats as juveniles, to remain close to suitable habitats, rather than being swept off to less favourable habitats (Breitburg et al., 1995).

The observed diversification in larval distribution links dispersal to processes such as, spawning strategy, ontogenetic stage, pelagic larval duration and advective oceanographic processes (Sponaugle et al., 2002; Werner et al., 2007). Coupled with coastal ocean currents, larval behaviour can further influence transport through active vertical positioning in the water column (Parrish et al., 1981; Boehlert and Mundy, 1988). While hydrodynamic conditions are clearly important to larval transport and retention, our data suggest that spawning strategy and life history are linked to behaviours that are critically important and lead to a variety of responses to the same physical conditions.

While coastal fronts may serve to accumulate larvae of coastal species onshore, the dynamic nature of frontal hydrography can also result in increased dispersal when fast currents prevail, with important implications on larval connectivity. Local small-scale hydrographic variability in coastal frontal events can therefore exert a powerful influence on fish larvae with potential ecologically meaningful effects on population connectivity. Repeated measurements of physical conditions and larval abundances illustrated clear links between on/off shore current direction and life history of different fish assemblages.

\section{DATA AVAILABILITY STATEMENT}

The original contributions presented in the study are included in the article/Supplementary Material, further inquiries can be directed to the corresponding author.

\section{ETHICS STATEMENT}

The animal study was reviewed and approved by the South African Institute for Aquatic Biodiversity reference number (2014/07).

\section{REFERENCES}

Acha, E. M., Mianzan, H. W., Guerrero, R. A., Favero, M., and Bava, J. (2004). Marine fronts at the continental shelves of austral South America: physical and ecological processes. J. Mar. Syst. 44, 83-105. doi: 10.1016/J.JMARSYS.2003.09. 005

Aghsaee, P., Boegman, L., and Lamb, K. G. (2010). Breaking of shoaling internal solitary waves. J. Fluid Mech. 659, 289-317. doi: 10.1017/S002211201000248X

Almany, G. R., Berumen, M. L., Thorrold, S. R., Planes, S., and Jones, G. P. (2007). Local replenishment of coral reef fish populations in a marine reserve. Science 316, 742-744. doi: 10.1126/science.1140597

Anderson, M., and Braak, C. T. (2003). Permutation tests for multi-factorial analysis of variance. J. Stat. Comput. Simul. 73, 85-113. doi: 10.1080/ 00949650215733

Bakun, A. (1997). Patterns in the ocean: ocean processes and marine population dynamic. Rev. Fish Biol. Fish. 7, 382-384.

Bakun, A. (2006). Fronts and eddies as key structures in the habitat of marine fish larvae: opportunity, adaptive response and competitive advantage. Sci. Mar. 70, 105-122. doi: 10.3989/scimar.2006.70s2105

\section{AUTHOR CONTRIBUTIONS}

FP and NW developed the research idea and designed the experiment. PP, NW, and FP collected the data. WG, NW, and JJ analysed the oceanographic data. PP wrote the manuscript with significant contributions from NW, WG, CM, FP, and JJ. All authors provided critical feedback and helped shape the research, analysis and manuscript.

\section{FUNDING}

This work was supported by the South African Institute for Aquatic Biodiversity-National Research Foundation of South Africa (SAIAB-NRF) Institutional support system by the African Coelacanth Ecosystem Programme (ACEP; grant number 64801). CM was supported by the South African Research Chairs Initiative of the National Research Foundation (grant number 64801). The Claude Leon Foundation is thanked for providing a postdoctoral fellowship to PP. During data processing and manuscript elaboration NW was funded by the NASA grant 80NSSC20K0074.

\section{ACKNOWLEDGMENTS}

We thank the captain, Koos Smith, and crew of the RV uKwabelana, Ryan Palmer, Jacqui Trassierra, Shana Mian, Olwethu Duna, and Carlota Fernández for assistance and data collection. We acknowledge use of infrastructure and equipment provided by the South African Institute for Aquatic Biodiversity Research Platform.

\section{SUPPLEMENTARY MATERIAL}

The Supplementary Material for this article can be found online at: https://www.frontiersin.org/articles/10.3389/fevo.2021. 684502/full\#supplementary-material

Beckley, L. E. (1986). The ichthyoplankton assemblage of the Algoa Bay nearshore region in relation to coastal zone utilization by juvenile fish. S. Afr. J. Zool. 21, 244-252. doi: 10.1080/02541858.1986.11447990

Benjamini, Y., and Hochberg, Y. (1995). Controlling the false discovery rate: a practical and powerful approach to multiple testing. J. R. Stat. Soc. Ser. B 57, 289-300. doi: 10.1111/j.2517-6161.1995.tb02031.x

Black, K. P., Gay, S. L., and Andrews, J. C. (1990). Residence times of neutrallybuoyant matter such as larvae, sewage or nutrients on coral reefs. Coral Reefs 9 , 105-114. doi: 10.1007/BF00258221

Boehlert, G. W., and Mundy, B. C. (1988). Roles of behavioral and physical factors in larval and juvenile fish recruitment to estuarine nursery areas. Am. Fish. Soc. Symp. 3, 51-67.

Bolle, L. J., Dickey-Collas, M., van Beek, J. K. L., Erftemeijer, P. L. A., Witte, J. I. J., Van der Veer, H. W., et al. (2009). Variability in transport of fish eggs and larvae. III. Effects of hydrodynamics and larval behaviour on recruitment in plaice. Mar. Ecol. Prog. Ser. 390, 195-211. doi: 10.3354/meps0 8177

Bradbury, I. R., and Snelgrove, P. V. R. (2001). Contrasting larval transport in demersal fish and benthic invertebrates: the roles of behaviour and advective 
processes in determining spatial pattern. Can. J. Fish. Aquat. Sci. 58, 811-823. doi: 10.1139/f01-031

Breitburg, D. L., Palmer, M. A., and Loher, T. (1995). Larval distributions and the spatial patterns of settlement of an oyster reef fish: responses to flow and structure. Mar. Ecol. Prog. Ser. 125, 45-60. doi: 10.3354/meps 125045

Brewer, G. D., and Kleppel, G. S. (1986). Diel vertical distribution of fish larvae and their prey in nearshore waters of southern California. Mar. Ecol. Prog. Ser. 27, 217-226. doi: 10.3354/meps027217

Brogan, M. W. (1994). Distribution and retention of larval fishes near reefs in the Gulf of California. Mar. Ecol. Prog. Ser. 115, 1-13. doi: 10.3354/meps115001

Cowen, R. K. (2002). "Larval dispersal and retention and consequences for population connectivity," in Coral Reef Fishes, Dynamics and Diversity in a Complex Ecosystem, ed. P. F. Sale (San Diego, CA: Academic), 149-170. doi: 10.1016/b978-012615185-5/50010-4

Cowen, R. K., and Castro, L. R. (1994). Relation of coral reef fish larval distributions to island scale circulation around Barbados, West Indies. Bull. Mar. Sci. 54, 228-244.

Franks, P. J. S. (1992a). Phytoplankton blooms at fronts: patterns, scales, and physical forcing mechanisms. Rev. Aquat. Sci. 6, 121-137.

Franks, P. J. S. (1992b). Sink or swim: accumulation of biomass at fronts. Mar. Ecol. Prog. Ser. 82, 1-12. doi: 10.3354/meps082001

Genin, A., Jaffe, J. S., Reef, R., Richter, C., and Franks, P. J. (2005). Swimming against the flow: a mechanism of zooplankton aggregation. Science 308, 860862. doi: $10.1126 /$ science. 1107834

Graber, H. C., and Limouzy-Paris, C. B. (1997). Transport patterns of tropical reef fish larvae by spin-off eddies in the Straits of Florida. Oceanography 10, 68-71.

Greer, A. T., Cowen, R. K., Guigand, C. M., Hare, J. A., and Tang, D. (2014). The role of internal waves in larval fish interactions with potential predators and prey. Prog. Oceanogr. 127, 47-61. doi: 10.1016/j.pocean.2014.05.010

Hameed, S. O., White, J. W., Miller, S. H., Nickols, K. J., and Morgan, S. G. (2016). Inverse approach to estimating larval dispersal reveals limited population connectivity along $700 \mathrm{~km}$ of wave-swept open coast. Proc. R. Soc. B Biol. Sci. 283:20160370. doi: 10.1098/rspb.2016.0370

Holliday, D., Beckley, L. E., and Olivar, M. P. (2011). Incorporation of larval fishes into a developing anti-cyclonic eddy of the Leeuwin Current off south-western Australia. J. Plankton Res. 33, 1696-1708. doi: 10.1093/plankt/fbr064

Jackson, J. M., Rainville, L., Roberts, M. J., McQuaid, C. D., and Lutjeharms, J. R. E. (2012). Mesoscale bio-physical interactions between the Agulhas Current and the Agulhas Bank, South Africa. Continent. Shelf Res. 49, 10-24. doi: 10.1016/j. csr.2012.09.005

Kingsford, M., Wolanski, E., and Choat, J. (1991). Influence of tidally induced fronts and Langmuir circulations on distribution and movements of presettlement fishes around a coral reef. Mar. Biol. 109, 167-180. doi: 10.1007/ bf01320244

Kingsford, M. J. (1988). The early life history of fish in coastal waters of northern New Zealand: a review. N. Zeal. J. Mar. Freshw. Res. 22, 463-479. doi: 10.1080/ 00288330.1988 .9516316

Kingsford, M. J. (1990). Linear oceanographic features: a focus for research on recruitment processes. Austral. Ecol. 15, 391-401. doi: 10.1111/j.1442-9993. 1990.tb01465.x

Kingsford, M. J., and Choat, J. H. (1986). Influence of surface slicks on the distribution and onshore movements of small fish. Mar. Biol. 91, 161-171. doi: $10.1007 /$ bf00569432

Kingsford, M. J., and Choat, J. H. (1989). Horizontal distribution patterns of presettlement reef fish: are they influenced by the proximity of reefs? Mar. Biol. 101, 285-297. doi: 10.1007/bf00428124

Laprise, R., and Dodson, J. J. (1993). Nature of environmental variability experienced by benthic and pelagic animals in the St. Lawrence Estuary, Canada. Mar. Ecol. Prog. Ser. 94, 129-139. doi: 10.3354/meps094129

Laprise, R., and Pepin, P. (1995). Factors influencing the spatio-temporal occurrence of fish eggs and larvae in a northern, physically dynamic coastal environment. Mar. Ecol. Prog. Ser. 122, 73-92. doi: 10.3354/meps 122073

Lasker, R. (1975). Field criteria for survival of anchovy larvae: the relation between inshore chlorophyll maximum layers and successful first feeding. Fishery Bull. 73, 453-462.

Lasker, R. (1978). The relation between oceanographic conditions and larval anchovy food in the California Current: identification of factors contributing to recruitment failure. Rapports et Procès-Verbaux des Réunions. Conseil Int. pour I'Exploration de laMer 173, 212-230.

Lecchini, D., Shima, J., Banaigs, B., and Galzin, R. (2005). Larval sensory abilities and mechanisms of habitat selection of a coral reef fish during settlement. Oecologia 143, 326-334. doi: 10.1007/s00442-004-1805-y

Lee, O., Nash, R. D. M., and Danilowicz, B. S. (2005). Small-scale spatio-temporal variability in ichthyoplankton and zooplankton distribution in relation to a tidal-mixing front in the Irish Sea. ICES J. Mar. Sci. 62, 1021-1036. doi: 10.1016/j.icesjms.2005.04.016

Leichter, J. J., Shellenbarger, G., Genovese, S. J., and Wing, S. R. (1998). Breaking internal waves on a Florida (USA) coral reef: a plankton pump at work? Mar. Ecol. Prog. Ser. 166, 83-97. doi: 10.3354/meps166083

Leis, J. M. (1984). Larval fish dispersal and the East Pacific barrier. Oceanogr. Trop. $19,181-192$.

Leis, J. M. (1991a). “The pelagic stage of reef fishes: the larval biology of coral reef fishes," in The Ecology of Fishes on Coral Reefs, ed. P. F. Sale (New York: Academic Press), 183-230. doi: 10.1016/b978-0-08-092551-6.50013-1

Leis, J. M. (1991b). Vertical distribution of fish larvae in the Great Barrier Reef lagoon, Australia. Mar. Biol. 109, 157-166. doi: 10.1007/bf01320243

Leis, J. M., and Carson-Ewart, B. M. (2000). The Larvae of Indo-Pacific Coastal Fishes: An Identification Guide to Marine Fish Larvae. Leiden: Koninklijke Brill.

Leis, J. M., and Miller, J. M. (1976). Offshore distributional patterns of Hawaiian fish larvae. Mar. Biol. 36, 359-367. doi: 10.1007/bf00389198

Liévana MacTavish, A., Ladah, L. B., Lavín, M. F., Filonov, A., Tapia, F. J., and Leichter, J. (2016). High frequency (hourly) variation in vertical distribution and abundance of meroplanktonic larvae in nearshore waters during strong internal tidal forcing. Continent. Shelf Res. 117, 92-99. doi: 10.1016/j.csr.2016. 02.004

Limouzy-Paris, C. B., Graber, H. C., Jones, D. L., Röpke, A. W., and Richards, W. J. (1997). Translocation of larval coral reef fishes via sub-mesoscale spin-off eddies from the Florida current. Bull. Mar. Sci. 60, 966-983.

Lough, R. G., and Manning, J. P. (2001). Tidal-front entrainment and retention of fish larvae on the southern flank of Georges Bank. Deep Sea Res. Part II 48, 631-644. doi: 10.1016/s0967-0645(00)00130-2

Marliave, J. B. (1986). Lack of planktonic dispersal of rocky intertidal fish larvae. Trans. Am. Fish. Soc. 115, 149-154. doi: 10.1577/1548-8659(1986)115<149: lopdor $>2.0 . \mathrm{co} ; 2$

McCulloch, A., and Shanks, A. L. (2003). Topographically generated fronts, very nearshore oceanography and the distribution and settlement' of mussel larvae and barnacle cyprids. J. Plankton Res. 25, 1427-1439. doi: 10.1093/plankt/ fbg098

Morgan, S. G., Miller, S. H., Robart, M. J., and Largier, J. L. (2018). Nearshore larval retention and cross-shelf migration of benthic crustaceans at an upwelling center. Front. Mar. Sci. 5:161. doi: 10.3389/fmars.2018.00161

Moser, H. G., and Smith, P. E. (1993). Larval fish assemblages and oceanic boundaries. Bull. Mar. Sci. 53, 283-289. doi: 10.1002/9780470959862.ch10

Moser, H. G., Richards, W. J., Cohen, D. M., Fahay, M. P., Kendall, A. W., and Richardson, S. L. (1984). Ontogeny and Systematics of Fishes, American Society of Ichthyologists and Herpetologists Special Publication. Lawrence: American Society of Ichthyologists and Herpetologists.

Mullaney, T. J., and Suthers, I. M. (2013). Entrainment and retention of the coastal larval fish assemblage by a short-lived, submesoscale, frontal eddy of the East Australian current. Limnol. Oceanogr. 58, 1546-1556. doi: 10.4319/lo.2013.58. 5.1546

Myers, R. A., and Pepin, P. (1994). Recruitment variability and oceanographic stability. Fish. Oceanogr. 3, 246-255. doi: 10.1111/j.1365-2419.1994.tb00102.x

Neira, F. J., Miskiewicz, A. G., and Trnski, T. (1998). Larvae of Temperate Australian Fishes: Laboratory Guide for Larval Fish Identification. Nedlands: University of Western Australia Press.

Norcross, B. L., and Shaw, R. F. (1984). Oceanic and estuarine transport of fish eggs and larvae: a review. Trans. Am. Fish. Soc. 113, 153-165. doi: 10.1577/ 1548-8659(1984)113<153:oaetof $>2.0$. co;2

Paris, C. B., and Cowen, R. K. (2004). Direct evidence of a biophysical retention mechanism for coral reef fish larvae. Limnol. Oceanogr. 49, 1964-1979. doi: 10.4319/lo.2004.49.6.1964

Paris, C. B., Cowen, R. K., Lwiza, K. M. M., Wang, D.-P., and Olson, D. B. (2002). Multivariate objective analysis of the coastal circulation of Barbados, 
West Indies: implication for larval transport. Deep Sea Res. I 49, 1363-1386. doi: 10.1016/s0967-0637(02)00033-x

Parrish, R. H., Nelson, C. S., and Bakun, A. (1981). Transport mechanisms and reproductive success of fishes in the California current. Biol. Oceanogr. 1, 175-203.

Pattrick, P., and Strydom, N. A. (2008). Composition, abundance, distribution and seasonality of larval fishes in the shallow nearshore of the proposed Greater Addo Marine Reserve, Algoa Bay, South Africa. Estuar. Coast. Shelf Sci. 79, 251-262. doi: 10.1016/j.ecss.2008.04.009

Pattrick, P., and Strydom, N. A. (2014). Larval fish variability in response to oceanographic features in a nearshore nursery area. J. Fish Biol. 85, 857-881. doi: $10.1111 /$ jb. 12477

Pineda, J. (1994). Internal tidal bores in the nearshore: warm-water fronts, seaward gravity currents and the onshore transport of neustonic larvae. J. Mar. Res. 52, 427-458. doi: 10.1357/0022240943077046

Pineda, J. (1999). Circulation and larval distribution in internal tidal bore warm fronts. Limnol. Oceanogr. 44, 1400-1414. doi: 10.4319/lo.1999.44.6.1400

Pineda, J., Hare, J. A., and Sponaugle, S. (2007). Larval transport and dispersal in the coastal ocean and consequences for population connectivity. Oceanography 20, 22-39. doi: 10.5670/oceanog.2007.27

Porri, F., Jackson, J. M., Von der Meden, C. E. O., Weidberg, N., and McQuaid, C. D. (2014). The effect of mesoscale oceanographic features on the distribution of mussel larvae along the south coast of South Africa. J. Mar. Syst. 132, 162-172. doi: 10.1016/j.jmarsys.2014.02.001

R Development Core Team (2019). R: A Language and Environment for Statistical Computing. Vienna: R Foundation for Statistical Computing.

Reiss, C. S., Panteleev, G., Taggart, C. T., Sheng, J., and DeYoung, B. (2000). Observations on larval fish transport and retention on the Scotian Shelf in relation to geostrophic circulation. Fish. Oceanogr. 9, 195-213. doi: 10.1046/j. 1365-2419.2000.00139.x

Richards, C., Bourgault, D., Galbraith, P. S., Hay, A., and Kelley, D. E. (2013). Measurements of shoaling internal waves and turbulence in an estuary. J. Geophys. Res. Oceans 118, 273-286. doi: 10.1029/2012JC008154

Rissik, D., and Suthers, I. M. (1996). Feeding in a larval fish assemblage: the nutritional significance of an estuarine plume front. Mar. Biol. 125, 233-240. doi: $10.1007 / \mathrm{bf} 00346303$

Rodríguez, J. M., Barton, E. D., Hernández-Leó, S., and Arístegui, J. (2004). The influence of mesoscale physical processes on the larval fish community in the Canaries CTZ, in summer. Prog. Oceanogr. 62, 171-188. doi: 10.1016/j.pocean. 2004.07.006

Roura, Á, Amor, M., González, ÁF., Guerra, Á, Barton, E. D., and Strugnell, J. M. (2019). Oceanographic processes shape genetic signatures of planktonic cephalopod paralarvae in two upwelling regions. Prog. Oceanogr. 170, 11-27. doi: 10.1016/J.POCEAN.2018.10.005

Sale, P. F. (2004). Connectivity, recruitment variation, and the structure of reef fish communities. Integr. Comp. Biol. 44, 390-399. doi: 10.1093/icb/44.5.390

Schumann, E. H. (1987). The coastal ocean off the east coast of South Africa. Trans. R. Soc. S. Afr. 46, 215-228. doi: 10.1080/00359198709520125

Schumann, E. H. (1998). The coastal ocean off southeast Africa, including Madagascar. Sea 11, 557-582.

Shanks, A. (1983). Surface slicks associated with tidally forced internal waves may transport pelagic larvae of benthic invertebrates and fishes shoreward. Mar. Ecol. Prog. Ser. 13, 311-315. doi: 10.3354/meps013311

Shanks, A. L., and Eckert, G. L. (2005). Population persistence of California Current fishes and benthic crustaceans: a marine drift paradox. Ecol. Monogr. 75, 505-524. doi: 10.1890/05-0309

Shanks, A. L., McCulloch, A., and Miller, J. (2003). Topographically generated fronts, very nearshore oceanography and the distribution of larval invertebrates and holoplankters. J. Plankton Res. 25, 1251-1277. doi: 10.1093/plankt/fbg090

Shanks, A. L., and Pfister, C. A. (2009). Annual recruitment of three species of tidepool fishes is driven by variation in springtime coastal hydrodynamics. Limnol. Oceanogr. 54, 1481-1487. doi: 10.4319/lo.2009.54.5.1481

Slatkin, M. (1993). Isolation by Distance in Equilibrium and non-equilibrium populations. Evolution 47, 264-279. doi: 10.1111/j.1558-5646.1993.tb01215.x

Smith, M. M., and Heemstra, P. C. (1995). Smith's Sea Fishes. Johannesburg: Macmillan.

Sponaugle, S., Cowen, R. K., Shanks, A., Morgan, S., Leis, J. M., Pineda, J., et al. (2002). Predicting self-recruitment in marine populations: biophysical correlates and mechanisms. Bull. Mar. Sci. 70, 341-375.
Sponaugle, S., Fortuna, J., Grorud, K., and Lee, T. (2003). Dynamics of larval fish assemblages over a shallow coral reef in the Florida Keys. Mar. Biol. 143, 175-189. doi: 10.1007/s00227-003-1059-y

Sponaugle, S., Paris, C. B., Walter, K. D., Kourafalou, V., and Alessan, S. (2012). Observed and modeled larval settlement of a reef fish to the Florida Keys. Mar. Ecol. Prog. Ser. 453, 201-212. doi: 10.3354/meps09641

Stephenson, R. L., Power, M. J., Laffan, S. W., and Suthers, I. M. (2015). Tests of larval retention in a tidally energetic environment reveal the complexity of the spatial structure in herring populations. Fish. Oceanogr. 24, 553-570. doi: $10.1111 /$ fog. 12129

Suthers, I. M., and Frank, K. T. (1991). Comparative persistence of marine fish larvae from pelagic versus demersal eggs off southwestern Nova Scotia, Canada. Mar. Biol. 108, 175-184. doi: 10.1007/bf01344331

Swearer, S. E., Caselle, J. E., Lea, D. W., and Warner, R. R. (1999). Larval retention and recruitment in an island population of a coral-reef fish. Nature 402, 799-802. doi: $10.1038 / 45533$

Swieca, K., Sponaugle, S., Briseño-Avena, C., Schmid, M., Brodeur, R., and Cowen, R. (2020). Changing with the tides: fine-scale larval fish prey availability and predation pressure near a tidally modulated river plume. Mar. Ecol. Prog. Ser. 650, 217-238. doi: 10.3354/meps13367

Tiedemann, M., and Brehmer, P. (2017). Larval fish assemblages across an upwelling front: indication for active and passive retention. Estuar. Coast. Shelf Sci. 187, 118-133. doi: 10.1016/j.ecss.2016.12.015

Villegas-Ríos, D., Martínez, A., Palmero, A., and Azevedo, J. E. M. N. (2009). Early development stages of the red blenny, Parablennius ruber (Teleostei: Blenniidae). J. Mar. Biol. Assoc. U.K. 89, 605-608. doi: 10.1017/ S0025315408002646

Weidberg, N., Goschen, W. S., Jackson, J. M., Pattrick, P., McQuaid, C. D., and Porri, F. (2019). Fine scale depth regulation of invertebrate larvae around coastal fronts. Limnol. Oceanogr. 64, 785-802. doi: 10.1002/lno.11074

Weidberg, N., Lobón, C., López, E., García Flórez, L., Fernández-Reuda, M., del, P., et al. (2014). Effect of nearshore surface slicks on meroplankton distribution: role of larval behaviour. Mar. Ecol. Prog. Ser. 506, 15-30. doi: 10.3354/meps10777

Weidberg, N., Porri, F., Von der Meden, C. E. O., Jackson, J. M., Goschen, W. S., and McQuaid, C. D. (2015). Mechanisms of nearshore retention and offshore export of mussel larvae over the Agulhas Bank. J. Mar. Syst. 144, 70-80. doi: 10.1016/j.jmarsys.2014.11.012

Werner, F., Cowen, R. K., and Paris, C. B. (2007). Coupled biological and physical models. Present capabilities and necessary developments for future studies of population connectivity. Oceanography 20, 54-69. doi: 10.5670/oceanog. 2007.29

Whitney, J. L., Gove, J. M., McManus, M. A., Smith, K. A., Lecky, J., Neubauer, P., et al. (2021). Surface slicks are pelagic nurseries for diverse ocean fauna. Sci. Rep. 11:3197. doi: 10.1038/s41598-021-81407-0

Wolanski, E., and Hamner, W. M. (1988). Topographically controlled fronts in the ocean and their biological influence. Science 241, 177-181. doi: 10.1126/science. 241.4862.177

Woodson, C. B. (2018). The fate and impact of internal waves in nearshore ecosystems. Annu. Rev. Mar. Sci. 10, 421-441. doi: 10.1146/annurev-marine121916-063619

Woodson, C. B., and Litvin, S. Y. (2015). Ocean fronts drive marine fishery production and biogeochemical cycling. PNAS 112, 1710-1715. doi: 10.1073/ pnas. 1417143112

Woodson, C. B., McManus, M. A., Tyburczy, J. A., Barth, J. A., Washburn, L., Caselle, J. E., et al. (2012). Coastal fronts set recruitment and connectivity patterns across multiple taxa. Limnol. Oceanogr. 57, 582-596. doi: 10.4319/lo. 2012.57.2.0582

Conflict of Interest: The authors declare that the research was conducted in the absence of any commercial or financial relationships that could be construed as a potential conflict of interest.

Copyright $\odot 2021$ Pattrick, Weidberg, Goschen, Jackson, McQuaid and Porri. This is an open-access article distributed under the terms of the Creative Commons Attribution License (CC BY). The use, distribution or reproduction in other forums is permitted, provided the original author(s) and the copyright owner(s) are credited and that the original publication in this journal is cited, in accordance with accepted academic practice. No use, distribution or reproduction is permitted which does not comply with these terms. 